\title{
SOLMAZ, Sefer (2018), İbn Fazlan Seyahatnâmesi'ne Göre İtil Bulgarları, Konya: Çizgi Kitabevi, 152 s., ISBN: 978-605-196-201-6
}

\author{
Ahmet Hüdai KELEŞ*
}

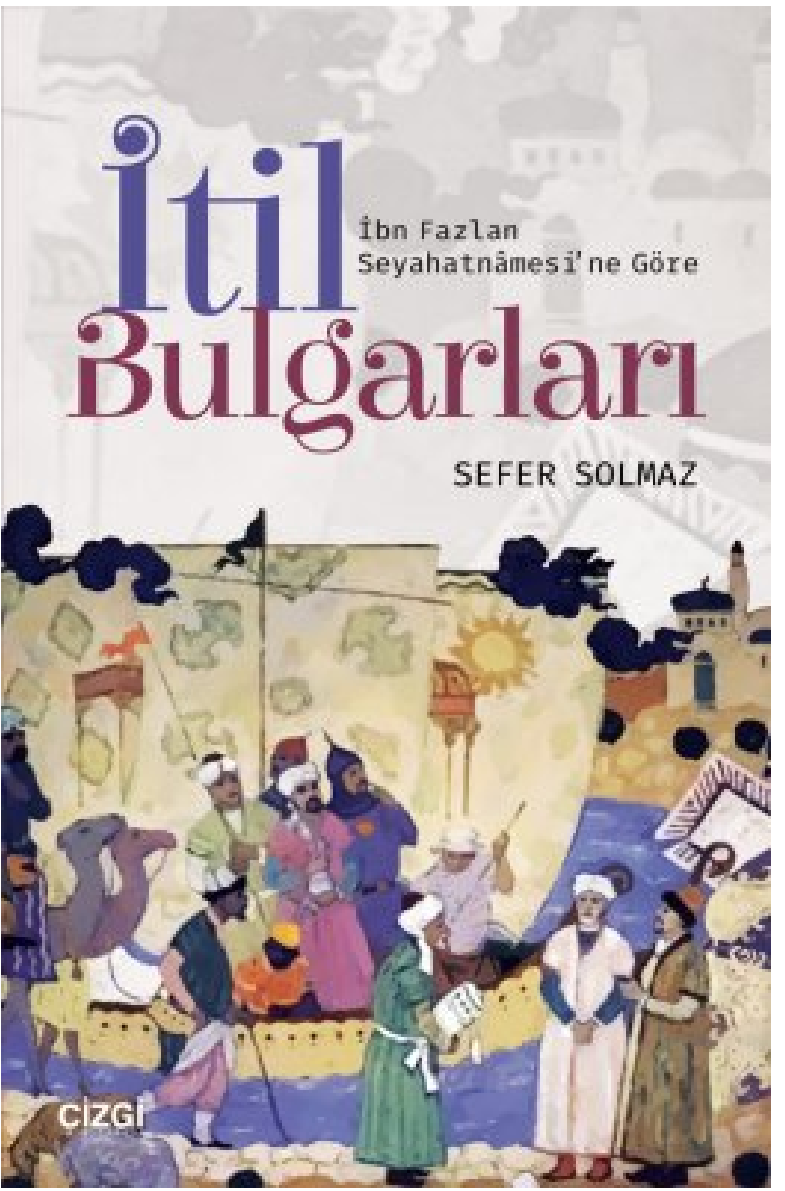

Bin yıla dayanan bir geçmişi olan Türk milleti, tarih boyunca birçok yere göç etmiş, devletler yıkmış ve devletler kurmuştur. Gerek anayurtlarında gerekse göç ettikleri bölgelerde yeni medeniyetler ortaya çıkaran Türk milleti, tarih yazıcılığında ise ne yazık ki bu kadar başarılı olamamıştır. İşte burada Türk tarihi ile ilgili bilgiler, ya komşu devletlerde ya da bir sebeple etkileşim içerisine girdiğimiz devletlerin kaynaklarında karşımıza çıkmaktadır. Tarihi kaynaklar, kendi içlerinde çeşitlilik göstermekle birlikte bunlardan birisi de seyahatnamelerdir. Yola çıtığı günden itibaren güzergâhları boyunca ilerleyen seyyahlar, gittikleri ya da gidecekleri devletler ile ilgili her anlamda bilgi verirken, yol üzerinde başlarına gelen maceraları da seyahatnamelerine eklemişlerdir. Türkler hakkında birçok seyyah eserlerinde önemli bilgiler vermiştir. Bu seyyahlardan birisi de İbn Fazlan olmuştur. Abbasi halifesi tarafından İtil Bulgar Devleti'ne gönderilen elçilik heyetinde bulunan İbn Fazlan, yaklaşık bir yıllık seyahati esnasında gördüklerini, duyduklarını ve yaşadığı olayları kaleme almıştır. Yol güzergâhı üzerinde bulunan Türk devletleri ya da toplulukları hakkında da bizlere önemli bilgiler vermiştir. Bu bilgilerden birisi de son durak olan İtil Bulgarlarıdır. Bölgede yeterli kaynak olmamasından dolayı İbn Fazlan'ın kaleme almış

\footnotetext{
* Yüksek Lisans Öğrencisi, Selçuk Üniversitesi, Sosyal Bilimler Enstitüsü, Tarih Ana Bilim Dall, ahmthdai@gmail.com, http://orcid.org/0000-0003-3993-7223
} 
olduğu eser barındırdığı bilgiler bakımından oldukça kıymetlidir. Bu bilgileri verirken öznel davranmaktan kaçamayan İbn Fazlan kendisine karşı eleştiri, açıklama ve yorumlara açık kapı bırakmıştır. Bundan dolayı bu çalışma verilen bilgilerin yeniden değerlendirilerek, İtil Bulgarlarının bilinmeyen yahut anlaşılamayan yönlerine daha sağlıklı bakılmasına vesile olması amacıyla kaleme alınmıştır. Yerli ve yabancı birçok yazarın kaleme aldığı eserleri de kaynakçasında kullanan yazar, akıcı ve sade bir dil kullanmış, verilen bilgilerin anlaşılmasında bir zorluk çekilmemesini elinden geldiğince sağlamıştır. Ayrıca kitap, önsöz, giriş, üç bölüm, sonuç, bibliyografya ve ekler kısmından oluşmaktadır. Bununla birlikte ekler kısmına, verilen bilgileri destekleyecek şekilde harita ve soyağacı görselleri de ilave edilmiştir.

Giriş bölümü "Bulgar Adının Kökeni" ile başlayan eserde Bulgar adının ortaya çıkışı ve hangi kaynakta ilk defa bahsedildiğine yer verilmiştir. Yine bu bölümde Zeki Velidi Togan, Osman Karatay, Gy. Nemeth, Armin Vambery ve Geza Feher gibi yerli ve yabanc1 araştırmacıların konu ile ilgili görüşleri bizlere aktarılmıştır. Bölümün devamın da ise Büyük Bulgar Devleti'nin kuruluşu ve dağılma süreci anlatılmıştır. Devletin yıkılmasından sonra Kubrat Han'ın ikinci büyük oğlu Kotrag, VII. yüzyılın sonlarına doğru günümüz Tataristan topraklarında İtil Bulgar Devleti'ni kurmuştur. Verilen bilgiler arasında İtil Bulgarlarının İslamlaşması iki asır gibi uzun bir sürede gerçekleşirken, ticari faaliyetlerin onların İslam dinini kabul etmesinde etkili olduğu belirtilmiştir. VII. yüzyılın sonlarında ölülerin İslami usullere göre defnedilmesi örnek olarak bizlere açıklanmaktadır. Ayrıca devletin İslamlaşma süreci ile ilgili olarak klasik ve modern kaynaklardan görüşlere de yer verilen eserde, bu konunun önemine ciddi bir şekilde değinilmiştir. Dönemin İslâm dünyası liderliğini elinde bulunduran Abbasi Halifeliği ile ilişkiler kurmayı ihmal etmeyen Almuş Han, Bağdat'a elçilik heyeti yollamış ve Halife el-Mu'tazıd, bu ziyaretten oldukça memnun olmuştur. Halife, Bulgarların çoğunun Müslüman olduğunu öğrendikten sonra bu ziyarete karşılık İtil Bulgarlarına büyük bir heyet göndermiş ve ikili ilişkilerin gelişmesini sağlamıştır. Zaman zaman iki devlet arasındaki ilişkilerin aksadığı fakat gelişen olaylar neticesinde İtil Bulgarlarının, Abbasi Halifesi tarafından tanındığı ve devletin resmî olarak İslamiyet'i kabul ettiği sade bir dil ile bizlere aktarılmıştır.

Eserin birinci bölümü "SIYASII-IDARI-ASKER̂ิ YAPI" olarak belirlenmiştir. Öncelikle İtil Bulgar ülkesinin coğrafi yapısından bahsedilmiş ve ülkenin uzaklığı Cürcâniyye'ye 70 günlük mesafe uzaklıkta olduğu belirtilmiştir. Eserde 921 yılı Haziran ayında Bağdat'tan yola çıkan heyetin, 922 yılı Mayıs ayında Bulgar ülkesine vardığı açıklanmaktadır. İbn Fazlan'ın coğrafya hakkında fazla bilgi vermediği bizlere aktarılırken İtil Bulgar Devleti'nin bulunduğu coğrafi konum ve neden "İtil Bulgarları" denildiği yazar tarafından tarihsel bir yaklaşım ile okuyuculara aktarılmıştır. Coğrafyadan sonra devletin idari yapısı hakkında bilgiler veren eserde, hükümdar Almuş'un kilolu, iri cüsseli ve sesinin de korkutucu bir özellik taşıdığ belirtilmiştir. Ayrıca hükümdarın halkı ile arasında bir sorun olmadığı onun tek başına gezebildiği de örneklendirilmiştir. Hükümdarın kaldığı çadırdan da bahseden İbn Fazlan, 1000 'den fazla insanın çadıra sığabilecek şekilde büyük olduğundan bahsetmiştir. Ayrıca bu dönemde İtil Bulgarlarının yerleşik hayata tamamen geçmediği, modern kaynaklar vasıtasıyla Bulgarların konar-göçer bir yaşam sürdüğü bilgisi de eserde karşımıza çıkmaktadır. Hükümdarın dış ilişkileri konusunda da bizleri aydınlatan eser, Abbasi halifesinin göndermiş olduğu heyete büyük hürmetler gösterildiğini anlatmaktadır. Yoldan gelen heyete dört günlük dinlenme süresinin verilmesinin ardından beşinci gün halifenin gönderdiği heyeti huzuruna kabul eden hükümdar, kendisine hediye olarak gönderilen eşyaları ihtişamlı bir törenle kabul 
etmiştir. Daha sonra halifenin mektubu İbn Fazlan tarafından okunmuş ve bitiminde hep birlikte tekbirler getirilmiştir. Halifenin İlteber Almuş'un hanımına göndermiş olduğu hediyelerin takdimi ile artık İtil Bulgarları siyasi anlamda resmen tanınmış ve halife Bulgarları kendisine tâbi kılmıştır. Bunlarla birlikte incelediğimiz bu eser bizlere İtil Bulgarlarının sofra adabı, misafire hürmet gibi konularda hükümdarın ve ailesinin ne kadar hassas, dikkatli olduğunu da sade bir şekilde bizlere açılamaktadır. İlteber Almuş, elçilik heyeti geldiğinden beri halifeye duyduğu saygı ve sevgiyi her ortamda belli etmekteydi. Buna örnek olarak ise Almuş'un halifenin adını alması ve adını Cafer b. Abdullah olarak değiştirmesi yine bu eserde bizlerin karşısına çıkmaktadır. Devamında ise hükümdarın, Abbasi halifesinden istemiş olduğu para meselesi belirtilirken, hükümdarın neden para istediği, paranın neden gelmediği ve hükümdarın paranın gelmemesinden sonra ki tavrı da okuyuculara anlatılmıştır. Bu bölümün diğer önemli kısmında ise İtil Bulgar Devleti'nin Hazarlar ile olan akrabalık ilişkisi, kendine tâbi olan beylerle ilişkisi anlatılırken hükümdar hanımının da devlet içerisindeki konumundan ve öneminden bahsedilmiştir. Son olarak bu bölümde devletin askerî yapısı incelenmiştir. Eserde İbn Fazlan'ın askerî yapı ile ilgili fazla bilgi vermediği belirtilirken örnek olaylarla İtil Bulgarları'nın neden Hazarlardan çekindiği, Bulgar askerlerinin özellikleri ve onların ok kullanımındaki maharetine kadar önemli konular açiklanmıştır.

İkinci bölüm ise "SOSYO-EKONOMIK HAYAT" başlı̆̆ı ile karşımıza çıkmaktadır. Bölümün başlangıcında İbn Fazlan'ın bu bölgede yaşayanların yüzlerinin kanlı yahut hasta olduklarına dair gözlemleri yazar tarafından doğru şekilde açıklanarak yüzlerinin kanlı değil bölge insanının yaşadığı coğrafyaya, iklim şartlarına ve besin kaynaklarından ötürü olduğunu belirtmiştir. İbn Fazlan'ın seyahatnamesinde yer alan bazı asılsız bilgiler ise elimizde ki bu eserde açılanarak, doğruluk payının olmadığı açıklanmaktadır. Buna örnek olarak ise erkek ve kadınların çıplak bir şekilde beraber yıkandıklarına dair rivayettir. Yazar, bunun tamamen asılsız olduğunu, seyahatnamenin daha fazla ilgi görmesi için yazıldığını ve Türk âdetlerinde böyle bir durumun söz konusu dahi olmadığın bizlere anlatmıştır. Ayrıca yazar, İbn Fazlan'ın içinde bulunduğu elçilik heyetine gösterilen saygı ve sevginin, İbn Fazlan tarafından İtil Bulgarlarına karşı gösterilmediğini ve onları küçük gördüğünü belirtmektedir. Bu bölümde İtil Bulgarlarının günlük hayatı ile ilgili bilgiler daha çok karşımıza çıkmaktadır. Örneğin; yeni doğan çocuğun dedesi tarafından büyütülmesi, ölüm durumunda mirasçların belirlenmesi, evlere düşen yıldırım sonrası halkın bu olaya karşı tutumu ve zeki insanların Tanrıya hizmet düşüncesi birçok gelenek bizlere aktarılmaktadır. Ayrıca halk arasında kişinin cahil ya da kabiliyetsiz olduğu yahut olmadığı, idrarını yaparken üzerinde silah bulundurması ya da bulundurmaması ile belirlenebiliyordu. Silah üzerindeyken idrar yapan kişi cahil ve beceriksiz, silah üzerinde yokken idrarını yapan kişi ise bilgili ve becerikli olarak nitelendirilmekteydi. Bununla birlikte halk arasında köpek havlamasının kendilerine uğurlu geldiği bilgisi üzerine yazarımız bu konu hakkında ki görüşleri belirtmiş yerine göre tenkit dahi etmiştir. Bu bölümde dikkatimizi çeken bir diğer husus ise ölü gömme âdetleri, ölüm sonrası erkeklerin ağladığı ve sonrasındaki matem havasından bahsedilmiştir. Devamında ise halk arasında işlenen suçların cezaları hakkında bilgi verilmiştir. Kasten adam öldürmek kısas ile karşılık bulurken zina etmek ve hırsızlık yapmak çok daha acı sonuçlar doğurmaktadır. Yazar, eski Türklerde uygulanan cezai yaptırımları da bizlere hatırlatarak benzerlik ve farklılıkları da görmemizi sağlamıştır. Ekonomik olarak fazla bilgi sahibi olmamakla birlikte Hallace'de kurulan pazar, ithal edilen mallar ve Bulgar ülkesine gelen ticaret yolları hakkında da açıklamalar yer almaktadır. İtil Bulgar Devleti'nin vergileri hakkında da bilgi sahibi olmakla birlikte vergilerin içeriden ve dışarıdan alınan vergiler diye ikiye ayrıldığını görmekteyiz. İkinci bölümün son 
kısmında ise halkın tükettiği yiyecek ve içecekler, kullandıkları ve kullanmadıkları yağlar, ormanlarda bulunan bal ve yiyeceklerin korunma şekilleri de açık bir şekilde anlatılmış meyve ve içecekler hakkında da bilgi verilmiştir.

Üçüncü ve son bölümün başlı̆̆ı ise "KÜLTÜREL ve DINÎ̂ HAYAT" olarak belirlenmiştir. Öncelikle kültürel durum ele alınırken giyim kuşam konusunda sadece hükümdarın terzisinin Bağdatlı olduğu belirtilmekle birlikte İbn Fazlan, halkın hepsinin kalpak giydiğini ve hükümdarın karşısında bunu çıkartarak bir saygı gösterisinde bulunduklarını anlatmaktadır. Sanat konusunda ise kullanılan çadırların hepsinin kubbeli olduğu ve gergedan boynuzundan yapılmış tepsilerin olduğu bilgisi verilmektedir. Bu bölümde üzerinde durulan mühim mesele ise dinî durum olmuştur. Bu bölümde İlteber Almuş, halifeden İslam dinini öğretecek fakih, öğretmen ve cami, minber gibi mimari yapıları yapması için mühendisler istemiştir. Bununla birlikte hükümdarın hutbede isminin yanlış okunması, adını Cafer b. Abdullah olarak değiştirmesi meselesi de yine bu bölümde yazar tarafından bizlere anlatılmıştır. Kamet meselesi adı ile karşımıza çıan kısımda ise İbn Fazlan ve hükümdar Cafer b. Abdullah arasındaki üstü kapalı Hanefî ve Şâfî mezhebi tartışması hakkında bilgi verilmektedir. Ayrıca yazar bu bölümde, İbn Fazlan'ın kendisini üstün görme psikolojisine, İslâmiyet'in İtil Bulgar topraklarına nasıl geldiğine dair klasik ve modern kaynaklardan görüşler ile bu bölümü anlaşılır hâle getirmiştir. İtil Bulgarlarının dinî yaşayışı hakkında bilgi verilen son bölümde İbn Fazlan'ın Bulgar halkına namaz kılabilecek derecede sureler ve Kur'an öğretmiş olduğu karşımıza çıkmaktadır. Bölüm sonunda ise İbn Fazlan'ın hayret içerisinde bırakan bazı olaylara yer verilmiştir. Coğrafi farklılıklardan dolayı görmüş olduğu olaylarla birlikte "Yılanların Büyüklügü̈" ile birlikte"İri Yar Adam ve Hikayesi" ve sonrasında da "Iri Yar Adamin Öldürülmesi ve Cesedinin Büyüklüğ̈̈" hikayeleri de bu bölümün sonlarında yer almaktadır.

Sonuç bölümünde değerlendirmelerde bulunan yazar, İbn Fazlan Seyahatnamesinin önemine ve doğru anlaşılmasına değinmiştir. Ayrıca ilk Müslüman Türk devleti özelliği taşıyan İtil Bulgar Devleti'nin Türk örf ve âdetlerine sahip çıtığı bizlere önemle vurgulanmaktadır. Eserin sonunda ise keyifle inceleyebileceğimiz dört adet harita ile İtil Bulgar hanedanına ait bir soyağacı ile anlatılan bilgiler birleşmiş ve akıllarımızda unutulmayacak bir eser olarak yer etmiştir. 